How to cite this article:

Hathout, T., Abdul Rahman. R., \& Md. Nor, M. Z. (2020). The role of international commercial arbitration in enhancing foreign direct investment: Lessons for Algeria. UUM Journal of Legal Studies, 11(2), 225-243. https:// doi.org/10.32890/uumjls.11.2.2020.6949

\title{
THE ROLE OF INTERNATIONAL COMMERCIAL ARBITRATION IN ENHANCING FOREIGN DIRECT INVESTMENT: LESSONS FOR ALGERIA
}

\author{
${ }^{1}$ Takyeddine Hathout, ${ }^{2}$ Rohana Abdul Rahman \& \\ ${ }^{3}$ Mohd Zakhiri Md. Nor \\ School of Law, Universiti Utara Malaysia
}

${ }^{1}$ Corresponding author: takyeddineh@gmail.com

Received: 1/9/2019 Revised: 1/7/2020 Accepted: 15/7/2020 Published: 31/7/2020

\begin{abstract}
Following the upsurge and development in the globalized and emerging economies, commercial misunderstanding and disputes transcending national borders may also be on the rise. Such disputes can hamper the economic activities and operation within those emerging economies, in particular those activities related to foreign direct investment. National legal mechanisms may not be attractive to international investors. Instead, international commercial arbitration (ICA) could be a preferred choice of foreign investors through which contractual disputes can be resolved via an independent forum because it helps to foster market efficiency, facilitate foreign direct investment and protect the interest of foreign investors. To offer insights on this issue theoretically and empirically, this paper presents a logic-based and empirically-based conceptual discussion to investigate the influence of ICA on FDI, in particular its application in the context of Algeria and the importance of domestic courts' execution of arbitral awards. The paper finds that ICA is indispensable to contractual conflict resolution and can consequently assist FDI inflows into the country that entrenches it. Algeria may increase FDI inflows by strengthening the legal framework for arbitration through the enhancement of national laws relating to ICA and guaranteeing their effective execution and enforcement by the local judicial system.
\end{abstract}


Keywords: International commercial arbitration, foreign direct investment, Algeria.

\section{INTRODUCTION}

Given the progressively interrelated and globalized economy, economic growth and ascension of several countries to the status of emerging markets, there has been an astronomical increase in the rate of commercial disputes going beyond national borders. The occurrence of commercial disputes can be associated with matters affecting the interpretation of commercial agreements and practices as well as differences in religion, language, custom and culture of the participating international organizations and parties. Thus, it becomes imperative for the involved parties in the disputes to reach a consensus or an agreement among themselves rather than involving an external party to mediate in the conflict. Thus, the involvement of a court of law in the resolution of contractual conflicts is only desirable when private agents fail to reach a consensus (Cooter \& Ulen, 2012; Posner, 2011).

According to the Coase Theorem proposition, when the costs of transaction are low, bargaining between conflicting parties provides more efficient mechanism for resolving contractual disputes. It is asserted that private cooperation among individuals or organizations can be more efficient than solutions provided by the formal judicial system in contractual disputes. One of the appropriate mechanisms in the form of arbitration can be adopted to resolve contractual conflict, given that it is a mechanism that is more efficient in the reallocation of resources among conflicting parties than the mechanism provided by a court of law (Cayon, Correa, \& Espriella, 2018).

On the other hand, emerging countries have faced difficulties in providing an appropriate basic legal structure for the resolution of contractual conflicts, which is the basis of a free market economy. International arbitration can be an alternative dispute settlement mechanism as it acts on a private and independent basis to protect the contractual and property rights of foreign investors (Posner, 2011). International arbitration could be assumed to be a more efficient and effective mechanism because it helps to foster market 
efficiency by creating a resolution mechanism that is not restricted to a local jurisdiction. In practice, international arbitration is a soughtafter mechanism that is employed in the resolution of international contractual and commercial conflicts between trading multinational corporations and entities (Cayon, Correa, \& Espriella, 2018).

International commercial arbitration (ICA) is preferred due to its nature that gives privacy to the conflicting parties, provides decisions by experts in the field of dispute and the disputes are solved on the basis of commercial interests rather than in terms of a particular national jurisdiction (Posner, 2011).

Generally, emerging and developing economies open their trading doors to foreign direct investments (FDI). FDI denotes equity investment or holding in an organizational entity that conducts its operation in a nation other than the country of the investor (Habib, 2018). FDI has been found to have a key impact on the economic growth and advancement of these countries. Potentially the provisions of FDI must be offered together with a strong dispute settlement mechanism that is independent and acceptable to foreign investors. It is noted that commercial contracts transcending national borders are becoming more complicated and often need appropriate mechanisms of dispute resolution that are dependable and flexible. These dispute resolution strategies, including international commercial arbitration, provide the parties involved the freedom they require to come up with systems tailored to their disputes. Furthermore, the concept of arbitration is viewed by foreign investors as a method of risk mitigation through statutory assurance on enforcement of rights, access to justice, and due process (Pouget, 2013).

Although numerous researches on foreign direct investment (FDI), and arbitration have been widely adopted by multinational corporations (MNCs), there appears to be only a limited number of articles that discuss the effect of ICA on FDI, in particular several pertinent issues relating to ICA and FDI (Myburgh \& Paniagua, 2016). In addition, the report of the UN Conference on Trade and Development (UNCTAD) (2017) shows that the economy of Algeria stands closed comparatively and struggles to draw in FDI, although the country has a thriving domestic market. In 2017, the FDI of the country shrank $26 \%$ to $\$ 1.2$ billion year-on-year, although it was 
dispersed more evenly across different sectors. Arguably, the decline in the FDI is connected with the non-confidence of the foreign investors in the existing Algerian arbitration system, given that the system might not provide a level competing ground for disputes settlement associated with FDI (See Schwartz, 2009). Regarding international commercial contracts, the provisions of the arbitration system tend to be a crucial strategy for enhancing FDI (Myburgh \& Paniagua, 2016). This is so, given that commercial arbitration provides a level playing field for disputes settlement associated with FDI and, in turn, helps to reduce the FDI- related risks (Schwartz, 2009). Moreover, prompt enforcement of international arbitral verdict scan attracts enhanced FDI (Bangkok Post, 2012).

This paper argues that foreign investors are barely interested to invest in Algeria due to the lack of confidence in the current national dispute settlement mechanism both via litigation in the formal court of law, and alternative forum of arbitration. Hence the paper addresses the provisions of ICA as a catalyst to enhance FDI in Algeria.

Specifically, this paper examines the enforcement of international arbitral verdicts by domestic courts in Algeria. This focus is important considering the fact that the ability of a country to implement written contracts is a crucial comparative advantage determinant in economic terms (Nunn, 2007) and enforcement of such contracts by national courts is considered essential to enhance international investments relationships (Johnson, McMillan \& Woodru, 2002).

The paper is arranged in the following order. Section one addresses the problem at hand and states the objective of the discussion. Section two discusses the background of ICA, while the third section focuses on the effect of ICA on FDI in the Algerian context. Section four describes the arbitral awards enforcement in a host's domestic courts, and section five concludes the discussion and offers relevant implications for policy making in Algeria.

\section{International Commercial Arbitration (ICA) in Algeria}

This section briefly explains the African experience in terms of international commercial arbitration. The section further examines the legal application of ICA in Algeria. The availability of arbitration within the international arbitration framework is the focus. 
Existing studies (e.g. PricewaterhouseCoopers \& Queen Mary University, 2006) have found that over sixty-seven percent (67\%) of multinational companies generally show preference for arbitration (whether solely or jointly with existing alternative mechanisms of dispute resolution) over traditional litigation, to resolve transnational disputes. According to Schwartz (2009), the main role of commercial arbitration in any society is to offer a fair ground for disputes settlement associated with FDI, and thus, reduce the FDIrelated risks. On the other hand, policy reforms of the governments of emerging economies which eliminate constraints for foreign investors to resolve their disputes are very essential to prosper economic development. As stated by the Bangkok Post (2012), the Secretary General of the International Chamber of Commerce (ICC) notes the necessity to have a prompt way to resolve disputes and also ensure a prompt execution of arbitral verdicts in order to woo FDI. Some authors opined that bringing more FDI into countries would necessitate fast-tracking the arbitration, indicating entrenchment of time-bound arbitration where particular time limits will be exercised by the arbitrators (Zaiwalla, 2013).

ICA is a private international commercial dispute settlement system that makes it possible for multinational corporations to enforce contracts more effectively over domestic courts (Myburgh \& Paniagua, 2016). In this way, arbitration has the confidence of fast and efficient dispute settlement to secure the interests of foreign investors. ICA primarily provides the stipulated terms earlier agreed upon by the disputing parties involved in the contract, rather than by procedural rules or national legislation (Gualtier, 2014). Many commercial contracts have an arbitration clause declaring any dispute arising under the contract to be resolved through the arbitration system, not through litigation in court. Such an arbitration clause allows the parties involved to state the seat of arbitration, governing law and the procedural rules involved (Gualtier, 2014).

Arbitration may be "institutional" or "ad hoc" (Al-Tamimi, 2017; Gualtier, 2014). Normally the contract terms will determine the arbitration type. A situation where the parties involved agree to resolve any dispute by means of arbitral institution (for example the ICSID), is referred to as institutional arbitration. Alternatively, where the parties decide to set their own rules of arbitration, ad hoc arbitration 
arises. The conduct of an ad hoc arbitration is autonomously done by the parties involved, who are mainly empowered to make decisions relating to the forum, the steps that will be followed, the number of arbitrators, and all other things required for the administration of the arbitration. Both types of arbitration can be subject to national laws and also international treaties signed by the respective countries involved in the FDI. These laws embrace both substantive and procedural rules, and in case of institutional arbitration, the procedural rules of the related arbitral entity.

Once the arbitration proceeding is completed, the issue arises as to the execution of the arbitral awards. Any arbitral awards proffered by the institutional arbitration panel must be enforced through the native court in the home country, thus, leading to the juncture where foreign investors appear to distrust the local courts. The International Arbitration Survey revealed that many of the arbitral awards or verdicts are voluntarily paid out via settlements, thus, eventually not needing any enforcement proceedings by domestic courts (PwC, 2013). The willingness of the corporations towards adhering voluntarily to court verdicts is due partially to the weak probability that local courts in certain jurisdictions reject the execution of the verdict. The reports from ICC, which is a foremost arbitration center in Paris, reveal that only six percent $(6 \%)$ of all ICC awards were subjects of challenge in local courts, while only 0.5 percent $(0.5 \%)$ of awards were set separately (Mattli, 2001).

It is argued that the arbitration regimes and strategies of some countries are not in support of international commercial arbitration. The study conducted by the World Bank's Investment Across Borders indicates material differences in the effectiveness and efficiency of the arbitration regimes in different countries. Moreover, the International Arbitration Survey reported that in five percent (5\%) of instances, the parties involved resolved the arbitration on the ground that the enforcement of arbitration award in local courts would be difficult. The reasons that respondents expected to face problems in the implementation of international arbitration awards included inadequate knowledge of how arbitration works amongst the local judiciary, hostility of domestic courts towards foreign awards, and the perceived corruption of administrative court personnel $(\mathrm{PwC}$, 2013).According to PriceWater HouseCoopers (PWC) and Queen 
Mary University (2006), even if consideration is given to domestic courts in handling foreign corporations fairly, local corporations often have the privilege and opportunity over foreign investors, because local corporations are more conversant with the procedures of the local court, having advantage of their own language and lawyers.

The situation is compounded by the upsurge in capital investment in Africa leading to investment disputes skyrocketing (Habib, 2018). In the United Nations Economic Commission for Africa's report, which covered the years ranging between 1972 and 2014, it was found that 111 cases of international investment disputes involved African countries. The claimant (multinational corporations) in some of these cases had invoked the Bilateral Investment Treaty (BITs) violation. Among the concerned nations from Africa, Algeria was reported as the respondent in six (6) cases. In the provision and disputes settlement between the host countries and foreign investors through international arbitration, BITs has been playing a significant role, particularly under the World Bank's International Centre for Settlement of Investment Disputes (ICSID) Rules, or ad hoc arbitration under the Rules of UNCITRAL. Accordingly, the process of arbitration in relation to these BITs, as confirmed by Habib (2018), provides the parties greater ownership and control of the process and likewise sustains great appeal amid foreign investors.

It is noted that China spent USD 1.3 billion for the Africa "Belt and Road Initiative". China had chosen to create her own arbitration centers, which included the China Africa Joint Arbitration Centre (CAJAC) in Shanghai, making use of the rules of the Shanghai International Arbitration Centre, and similarly in Johannesburg as a subgroup under the umbrella of the "Arbitration Foundation of South Africa". CAJAC offers a cost-effective and neutral tool for settling commercial disputes involving African and Chinese parties (Habib, 2018).

Across several countries in the Middle East and North Africa (MENA) region, which include Algeria, the tradition of deferring a dispute to an independent third party to simply reach an amicable conciliatory solution has been an established practice. This is facilitated by the cultural and religious values of the region, which encourage a constructive settlement of disputes away from the channels of the court system, which are often overburdened (Al-Tamimi, 2017). 
In Algeria, commercial disputes could be settled via arbitration processes where parties have the autonomy to select any arbitral institution alongside the arbitrators' base on their personal volition. Following ratification of the New York Convention in 1989, for disputes concerning international contracts, affected parties regularly prefer Paris or Geneva to handle the arbitration, although disputes occur in Algiers. State-owned firms are approved by law to have resort towards international arbitration in circumstances concerning international commercial relations (Seghir \& Debbouch, 2018). According to Algerian law, an arbitration agreement can be evaluated after expressions of intent by the parties following a defined agreement. Where any such intent is not expressed by the parties, the law that governs the agreement on arbitration can be determined by virtue of the dispute, or that chosen by the arbitral tribunal ${ }^{1}$. The chosen governing law must have a connection with the disputing parties or the contract ${ }^{2}$.

Arbitration procedures are governed by the Algerian Civil and Administrative Procedures Code (CAPC). The CAPC entered into force on 25 February 2008 and exclusively regulates domestic and international arbitration procedures. In this law, most of the general rules applicable to arbitration proceedings are provided. This includes equal treatment principles between parties, the right of the parties to a fair trial, due process and an adversarial hearing, along with the adoption of the relevant characteristics of arbitration procedures such as the removal of the right to appeal arbitral awards and confidentiality, and privacy in arbitration (Seghir \& Debbouch, 2018).

Even though Algeria did not take any step to implement the UN Commission on International Trade Law [UNCITRAL] Model law on International Commercial Arbitration, the CAPC basically reflects the principles found in international treaties relating to arbitration ratified in Algeria, for instance the ICSID Convention and the New York Convention. The provisions of Article 1008 of CAPC are to the effect that any arbitral agreement reached before the occurrence of a dispute ought to be formally incorporated into the

Civil and Administrative Procedures Code. art. 1040.

2 Articles 1050 of the CAPC and 18 of the Algerian Civil Code. 
main agreement/contract or in any other document referred to by the arbitration agreement. This inclusion does not, however, render the arbitration agreement dependent on the legitimacy of the contract in question (Alliouch Kerboua Meziani Naima, 2010). The parties may come to a decision to bring their dispute to arbitration by having an arbitration agreement after the dispute has come up.

The parties cannot challenge the legitimacy of an arbitration agreement simply because the principal contract is void. This is in line with article 1040, 1008, 1012, and 1040 of the CAPC, which provides that it is mandatory on the parties to enter into a formal arbitral agreement which must be in writing or by any other electronic or physical methods of communication.8 In addition, local arbitration agreements are expected to designate the arbitrators and the modalities of their designation.

In accordance with Article 1048 of the CAPC, the reasons for awarding arbitral awards in both domestic and international arbitral proceedings must be provided. The Algerian judge shall, based on that reasons, decide whether or not the award should be converted into a court order for the sake of enforcement. In Algeria, arbitral awards are gladly enforceable on the condition that the party enforcing fulfils the requirements of CAPC concerning the enforcement and recognition of the arbitral award. Conversely, in practice, intricacies may crop up in the enforcement of international arbitral awards delivered outside Algeria owing to the lack of proficiency of some courts in Algeria. (Seghir \& Debbouch, 2018).

The provision of article 1031 of the CAPC provides that for arbitral awards rendered in Algeria on a dispute, the subject matter of such a dispute is res judicata -immediately the award is handed down. Although, international arbitral awards rendered in Algeria may perhaps be subject to dissolution in compliance with article 1058 of CAPC, the parties may decide to waive the right to seek annulment of the award. Where the parties decide to apply for annulment of the award, such applications should be submitted to the Court of Appeal for consideration where the arbitral award was rendered within a period of one month from the exact date of notification of the order of court for enforcement. Local arbitration awards may perhaps be subject to an appeal except where the parties agreed contrarily. 
Overall, disputes in Algeria may be settled via arbitration, and parties in dispute have the freedom to decide on an arbitral institution and the arbitrators at their lone discretion. It is worthy of note, however, that in the case of cases involving international contracts, parties usually choose Geneva or Paris as the seat. The reason is that there is a common mistrust in choosing a country in Africa as the arbitration seat and the common choices remain Paris, Singapore, London and Geneva because these countries are regarded as having court systems that are comparatively more arbitration friendly (Habib, 2018).

It is argued that efforts should be made to enhance the acceptability and the confidence in the choice of the parties in choosing an arbitration seat from African countries. Foreign investors and African parties should rest assured that when they choose an arbitration seat within African countries, it can aid an efficient process of resolving disputes. The essence of appointing a seat lies in the provision of the legal framework for arbitration and giving supervisory jurisdiction to the court in the vicinity of the arbitration seat (Habib, 2018).

CAPC is designed to exclusively regulate arbitration procedures. Save as otherwise agreed by the parties to the arbitration agreement, a meticulous party may perhaps have resort to pre-arbitration temporary measures enforceable by the courts in Algeria. No court can claim jurisdiction on the matter in dispute already pending before any arbitral tribunal or any subject of arbitration born out of a valid arbitration agreement. The arbitral award execution can be rejected where the party opposing the enforcement of a foreign arbitral award within Algeria applies to an Algerian court for a stay of enforcement of the award pending the conclusion of the annulment proceedings, or where the award contradicts the international public order. The party opposing the enforcement of foreign arbitral award in Algeria can request from an Algerian court for a stay of enforcement of the award pending the conclusion of the annulment proceedings. If the arbitral award is in the long run voided by the Algerian court of the seat, the party who obtained the annulment of the arbitral award may seek to enforce the foreign judgment in Algeria which has annulled the arbitral award in order to prevent any attempt at implementing the voided award; this is in tandem with article 605 of the CAPC.

The discussion above is to the effect that Algeria has been able to make provisions for the basic legal structure dealing with the 
execution of international commercial arbitral awards. This paper, however does not seek to measure its effectiveness.

\section{Effect of ICA on FDI in Algerian Context}

FDI is one of the most essential mechanisms of cross-border capital flow into developing nations (Waglé, 2011). FDI fosters economic growth through the transfer of technology and capital that helps to improve the production capacity of the recipient party. To foster FDI, it is imperative that there is an adequate commercial regime, a solid legal framework, and political stability. However, there is empirical evidence that FDI can have negative effects or no effect at all on economic growth in emerging countries (Parviz, 2016).

Organizations decide to serve international markets by establishing foreign branches and subsidiaries, and not through licensing arrangements or export. This is because organizations that have ownership advantages tend to have an opportunity of becoming international because they seek to internalize their proprietary assets (distributional efficiency, brand and technology) while taking advantage of location-specific benefits like access to factors of production or market size (Waglé, 2011). FDI can either be vertical (efficiency-seeking) or horizontal (market-seeking), but most contemporary multinational organizations combine horizontal and vertical models of FDI. This is referred to as a knowledge-capital model, in which activities are divided across geographical locations based on differing intensities of skill (Markusen, 1997).

The effect of FDI on the growth of emerging nations in terms of economy, especially the countries that make up Africa cannot be underestimated. The African continent is now the fastest growing region for FDI in the world. As reported by Habib (2018), it is found in the study conducted by the Financial Times data division (2015) that in the year 2014, Africa gained a 65\% capital investment increase. In the continent, the volume of FDI projects increased by $6 \%$. The finding of the study indicates that capital inflow into African countries is left at its core resources with the investment mostly moving to the oil and gas industry and this is followed by real estate and communications. 
Moreover, different contracts that cut across international boundaries have the tendency of falling under the umbrella of the international commercial arbitration. Therefore, adjudication of disagreements using arbitration comprises the ones emanating from joint ventures, distribution agreements, and provision of goods and services agreements (UNCITRAL, 2008). The process of resolution is binding, non-judicial and private. According to Mattli (2001) most cases of arbitration come up based on a contract reached in the earlier or original agreement to transfer disputes involving contract to arbitration. Arbitrations frequently come up under the regulations of arbitration centers (institutional arbitration). This refers to centers in Singapore, London, Paris, Stockholm and Hong Kong (Myburgh \& Paniagua, 2016).

It is worthy of note that about eighty percent $(80 \%)$ of private international contracts contain provisions that make stipulation for sending disputes to arbitration. According to Sanders, Schultsz and Berg (1982) the international business community regards arbitration as an ordinary way of resolving disputes that emanate from international transactions. In this way, arbitration has global recognition and acceptance as the principal and favored tool for settling disputes.

ICA is beneficial to parties in dispute in numerous ways, i.e. litheness, secrecy and less expensive. Unlike domestic courts, ICA is more flexible. The parties have power to determine the numbers of arbitrator on the tribunal, the seat of arbitration, the arbitrators' selection process, the tribunal's powers and the applicable law. This level of flexibility is also extended to the choice of arbitration centers. The rules are adaptable by the parties in reaction to the organizational desires of making use of their services. According to Mattli (2001), the arbitration centers are required to regularly react to the desires of organizations through the creation of services that are new and accordingly updating their rules. For example, there is room for the selection of the law, arbitrators who are specialized in commercial law, and the appointment of industry professional arbitrators who have the capacity of making several realistic determinations more precisely than a jury or a judge (Bernstein, 2001).

Arbitration also enhances the option of the parties regarding the legal jurisdiction adopted during the formation of the contract. 
It is beneficial that the award and the proceedings can both be confidentially handled, hence the parties can circumvent the reputational expenses connected with public hearing, as well as the likely disclosure of susceptible commercial information (Mattli, 2001). Furthermore, the application of international arbitration, according to Bhattacharya, Galpin and Haslem (2007) decreases the rate of organizational home advantage of the domestic court.

The application of arbitration in adjudicating disputes appears more costly than making use of domestic courts. In the research conducted by Mistelis (2004), it was found that respondents preferred arbitration, but it was held to be of high cost and lengthy proceedings. The higher arbitration cost is a product of many factors. The transport fare of the lawyers engaged and the witnesses from their country for the hearing in the third country often have to be borne by the parties. This tends to add to the arbitration costs above the cost of a similar case having the comparable complexity and length in domestic courts. Contractual cases that make reference to English or American law will make use of solicitors who specialized in this law, and who are also based, for example in London or New York. Given the arbitration's high cost, Casella (1996) recommended that parties should only make use of arbitration for contractual disputes that involve larger amounts.

Although arbitration could be costly and lengthy, ICA would foster FDI and could lead to the growth in the flows of FDI, because foreign investors would prefer entrenchment of ICA in their host country, in particular within BITs treaty (Mistelis, 2004). ICA has been found to play a significant role in the enforcement of contracts, and this makes it an indispensable strategy to stimulate and attracts investors to a country (Myburgh \& Paniagua, 2016). This cost increase principally comes up via a change in the investment volume with a smaller impact on the volume of investment projects. In the research conducted by Cayon, Correa and Espriella (2018), it is observed that international arbitration has good influence on the development of domestic economy including FDI (see Bangkok Post, 2012; Myburgh \& Paniagua, 2016; Schwartz, 2009).

As argued by Berkowitz, Moenius and Pistor (2006) the role of international arbitration on the pattern and nature of goods that 
countries export cannot be underestimated. Specifically, the countries with international arbitration regimes that are very effective tend to export goods that are more complex. The study of Wagle (2011) reveals that a positive link exists between arbitration quality and FDI. In the research conducted by Myburgh and Paniagua (2016), it is found that the arbitration regimes of countries have a positive influence on the FDI, demonstrating positive shock to nations' arbitration rules in joining the New York Convention to bring about a rise in the levels of bilateral FDI. The impact of arbitration brings about reduction in the costs related to domestic judicial systems, and the countries' arbitration regimes improvement will have a great influence on the FDI volume, instead of the volume of foreign projects. These findings signify that enhancing the arbitration regimes by countries tends to increase the volume of FDI and prevent the diversion of FDI. This could be done by strengthening the domestic laws relating to international commercial arbitration.

Osinbajo (2018) pointed out that the existence of an effective, efficient and strong mechanism for dispute resolution, such as arbitration, is crucial for encouraging investors, both local and foreign. This is so given that beyond pure economic fundamentals, investors, whether domestic or foreign, always want to be assured that there is a credible judicial system in place where disputes arising in the course of transactions would be easily and effectively resolved.

Nevertheless, based on UNCTAD's report (2017), despite Algeria having a domestic market that is thriving, the country's economy is still comparatively closed and struggles to attract FDI. As indicated in the previous section, FDI declined significantly in the year 2017, and this could be connected with the non-confidence of the foreign investors in the existing local arbitration system, which appears to be lacking of fair ground for disputes settlement associated with FDI (See Schwartz, 2009). The Algerian government and the stakeholders could reverse the position and enhance FDI flows in the country through strengthened and effective ICA, because ICA fosters enforcement of international contracts and serves as an important mechanism for facilitating FDI (Myburgh \& Paniagua, 2016). Algeria would need to enhance and smoothen the arbitral awards' enforcement as this will protect investors' rights. 


\section{Enforcement of Arbitral Awards in the Host's Domestic Court}

In consideration of the terms of the New York Convention (NYC), the procedure for recognizing foreign arbitral award can be the fundamental stage of arbitration. According to NYC, a domestic arbitration framework must be able to provide for national courts to give necessary recognition and legality to foreign arbitral awards. This implies that national courts have to impose foreign arbitral awards in situations where a party in debt fails to comply with the agreed terms (Pouget, 2013).

In the Algerian context, it is reported that difficulties do occur in implementing international arbitral awards that are not rendered in Algeria due to deficiency of expertise in some Algerian courts in this area. For instance, in the matter decided by the Supreme Court (Cour de cassation) of Algeria (in decision No. 54330923) dated 18th March 2010, an arbitral award was issued by the Refined Sugar Association of London on 27 May 1999 ordering the Respondent (Miltman Andicogy Corporation) to pay to the Appellant (American business entity) the amount of USD28,125,394.00. The difficulties that the parties experienced in respect of enforcement related mainly to misinterpretations by the Algerian lower courts of the provisions of the CAPC as to which court had jurisdiction to decide upon the foreign award enforceability. As a result, the case took ten (10) years for the Algerian Supreme Court to determine the appropriate court having jurisdiction (Seghir \& Debbouch, 2018).

Successful execution of foreign arbitral awards is vital for any foreign investor targeting for emerging economies that can provide business opportunities, legal assurance and timeliness. It also becomes important because foreign investors, more generally, often consider whether the host country recognizes and supports alternative dispute resolutions such as arbitration (Pouget, 2013).

Attracting foreign investors to fund FDI into Algeria would demand some adjustment to the handling of ICA in the country. Taking NYC seriously and the commitment to apply its provisions would raise confidence in the Algerian law and, in turn, allow foreign investment to flow in (Myburgh \& Paniagua, 2016). Gleanings from the case studies culled from the FDI Regulations database in 2012 reveal that 
about 557 days or 80 weeks are spent by disputing parties for the recognition and implementation of foreign arbitral awards in all the examined economies.

As indicated in Table 1, proceedings of recognition and execution of arbitral awards are conducted in the fastest way in the Eastern part of Asia and the Pacific region, while it takes a longer period in MENA countries and the longest time in South Asia. The duration of the proceedings is subjected to lots of rudiments like the number of required steps to implement the foreign arbitral award in each of the countries. In some countries, parties need to put up applications for the recognition of a foreign arbitral award before a competent court prior to its enforcement. The stage of recognition is the conversion of the arbitral award into a court judgment. However, some economies such as the Philippines, Georgia and Belarus permit this stage to be simultaneously conducted with the stage of enforcement of an arbitral award.

Table 1: Average Length of Recognition/Enforcement Proceedings by Region, in Weeks

\begin{tabular}{ll}
\hline East Asia and the Pacific & 39 weeks \\
High-Income OECD & 43 weeks \\
Sub-Saharan Africa & 65 weeks \\
Middle East and North Africa & 68 weeks \\
Eastern Europe and Central Asia & 75 weeks \\
Latin America and the Caribbean & 90 weeks \\
South Asia & 386 weeks \\
\hline
\end{tabular}

Source: Pouget, 2013.

\section{CONCLUSION}

Based on the foregoing discussion, the paper stresses that for FDI to be an attractive investment in Algeria, the domestic laws must provide for international commercial arbitration to protect the rights of foreign investors. The current state of laws relating to arbitration must be improved to allow local expertise and friendly court processes to be made available. Furthermore, this paper found that 
ICA has been entrenched in Algeria, and arbitral awards are readily enforceable, but it takes a longer time in MENA countries including Algeria. It is also noted that there are difficulties in enforcing an international arbitral award rendered outside Algeria due to the lack of expertise in some Algerian courts in this area.

Arguably, the Algerian government and stakeholders could reverse the bleak position and enhance FDI flows into the country through strengthened and effective ICA, because ICA fosters enforcement of international contracts via arbitration (Myburgh\& Paniagua, 2016). This is also substantiated by the fact that foreign arbitral awards enforcement is essential for foreign investors intending to invest in emerging economies that have abundant business opportunities and relevant legal assurance (Pouget, 2013).

This paper has revealed that ICA is indispensable to international contractual conflict resolution and consequently assists FDI flows into the country that entrenches it. Accordingly, a strong legal framework for arbitration will, in turn increase FDI (Osinbajo, 2018). It could also be suggested that a timely-and-cost-effective ICA system may draw the foreign investors to come and contribute towards the economic wellbeing of the countries.

\section{ACKNOWLEDGEMENT}

This research received no specific grant from any funding agency.

\section{REFERENCES}

Alliouch Kerboua Meziani Naima. (2010). L'Arbitrage Commercial International en Algérie, 25-26.

Al-Tamimi, E. (2017). International Commercial Arbitration in the MENA: Institutional v Ad Hoc: A wealth of choice. 83 Arbitration, 1, 14-20. Chartered Institute of Arbitrators.

Arbitrationhttp://www.pwc.com/gx/en/arbitration-dispute resolution/index.jhtml

Bangkok Post. (2012). Thailand needs better arbitration to attract FDI. Retrieved from http://www.intellasia.net/thailand-needsbetter-arbitration-to-attract-fdi-207998 
Berkowitz, D., Moenius, J., \& Pistor, K. (2006). Trade, law and product complexity. The Review of Economics and Statistics, 88, 363-373.

Bernstein, L. (2001). Private commercial law in the cotton industry: Creating cooperation through rules, norms, and institutions. Michigan Law Review, 99, 1724-1790.

Bhattacharya, U., Neal, G., \& Bruce, H. (2007). The home court advantage in international corporate litigation. Journal of Law and Economics, 50, 625-660 http://www.jstor.org/ stable/10.1086/519817

Casella, A. (1996). On market integration and the development of institutions: The case of international commercial arbitration. European Economic Review, 40, 115-186.

Casella, A. (1996). On market integration and the development of institutions: The case of international commercial arbitration. European Economic Review, 40, 155-186.

Cayon, C. E., Correa, J. S., \& Espriella, L. D. L. (2018). Does international arbitration affect economic growth in Latin America? WSEAS Transactions on Business and Economics, $5,505-511$.

Cooter, R., \& Ulen, T. (2012). Law and economics. Boston: Pearson Addison Wesley. docs/IAstudy_2006.pdf

Gualtier, S. (2014). International Commercial Arbitration. Retrieved from http://www.nyulawglobal.org/globalex/International_ Commercial_Arbitration.html

Habib, S. (2018). Impact of foreign direct investment on arbitration in Africa. Retrieved from http://arbitrationblog. kluwerarbitration.com/

Mattli, W. (2001). Private justice in a global economy: From litigation to arbitration. International Organization, 55, 919-947.

Mistelis, L. (2004). International Arbitration -Corporate Attitudes and Practices? 12 perceptions tested: Myths data and analysis research report. American Review of International Arbitration, 15.

Myburgh, A., \& Paniagua, J. (2016). Does international commercial arbitration promote foreign direct investment? The Journal of Law and Economics, 59(3), 597-627.

Nunn, N. (2007). Relationship-specificity, incomplete contracts and the pattern of trade. The Quarterly Journal of Economics, 122, 569-600. 
Parviz, A. (2016). GDP growth determinants and foreign direct investment causality: The case of Iran. The Journal of International Trade and Economic Development, 25(6), 897913.

Posner. (1998). Creating a legal framework for economic development. The World Bank Research Observer, 13(1), $1-11$.

Posner. (2011). Economic analysis of law. Frederick: Aspen Publishers.

Pouget, S. (2013). Arbitrating and mediating disputes: Benchmarking arbitration and mediation regimes for commercial disputes related to foreign direct investment. World Bank Policy Research Working Paper, no. 6632.

PricewaterhouseCoopers \& Queen Mary University. (2006). International Arbitration Study: Corporate Attitudes and Practices. Retrieved from http://www.arbitrationonline.org/

PwC. (2013). International Arbitration Survey 2013. Corporate choices in International.

Sanders, Pieter, Jan C. Schultsz, \& A. J. van den Berg (Eds.). (1982). The art of arbitration: Essays on international arbitration: Liber Amicorum Pieter Sanders, 12 September 19121982. Deventer, Netherlands: Kluwer Law and Taxation Publishers.

Schwartz, E.A. (2009). The role of international arbitration in economic development. International Trade and Business Law Review, 12, 127-139.

Seghir, M., \& Debbouch, M. (2018). Delos guide to arbitration places (GAP). (1st ed.). Bennani \& Associés LLP.

Simon, J., McMillan, J., \& Woodru, C. (2002). Courts and relational contracts. Journal of Law, Economics, and Organization, 18, 221-277.

UN Conference on Trade and Development (UNCTAD). (2017). Trade and Development Report 2017. Beyond Austerity: Towards a Global New deal. New York: United Nations Publication. Retrieved from https://unctad.org/en/ PublicationsLibrary/tdr2017_en.pdf

UNCITRAL. (2008). Model law on international commercial arbitration. Vienna: United Nations Publication.

Zaiwalla, Sarosh. (2013). Fast-track arbitration can help attract FDI. Sudipto Dey. Retrieved from http://www.businessstandard.com/article/opinion/fast-track-arbitrationcan-helpattract-fdi-sarosh-zaiwalla-113020400006_1.html 